\title{
Permissible Limitations to Freedom of Religion and Belief in Nigeria
}

\author{
Ahmed Salisu Garba \\ Bauchi State University, Gadau \\ ahmedgarbasalisu@gmail.com
}

\begin{abstract}
The application of permissible limitations to restrict freedom of religion and belief in Nigeria continues to generate debate among scholars. This article applies a socio-legal methodology to analyse the legal rationale that Nigerian courts have used in cases concerning limitations to freedom of religion or belief. First, the article explores the history of the legal frameworks for the protection of freedom of religion and belief including its limitation in Nigeria. Second, the article analyses Nigerian courts' interpretation of the concept with specific reference to the legal rational used. Third, the article investigates the application of the proportionality test to balance the regulatory power of the state and citizens' right to practice their religion. The article engages with case-law on freedom of religion, mostly from High courts and Court of Appeal in Nigeria. The article contains contributions from several scholars, religious groups, public officials, Non-Governmental Organisations obtained through interviews at their various offices.
\end{abstract}

\section{Keywords}

Nigeria - freedom of religion or belief - limitation clauses

\footnotetext{
* Ahmed Salisu Garba holds a PhD Degree in Public Law and has written and presented papers at different international conferences in the UK, USA and African Countries on Law and Religion related topics. He is also the Dean of Law/Head of Department of Private and Business Law at the Faculty of Law, Bauchi State University, Gadau in Nigeria.
} 
The imposition of restrictions on the right to freedom of religion and belief or an aspect of it by the government in Nigeria has been supported and opposed by scholars. ${ }^{1}$ For example, on the one hand, Tarwase supports government restriction on the right to preach one's religion because of its potential to cause religious disharmony and violence. ${ }^{2}$ On the other hand, Sam Amadi ${ }^{3}$ and Inibehe Effiong ${ }^{4}$ argued that the state should not regulate religious preaching at all-despite the provision of Section 45 of the Nigerian Constitution that allows the state to derogate from such rights to defend public order, public morality or to protect the right of others.

This article examines the jurisprudence of Nigerian courts on limitations to freedom of religion. It analyses the following questions using a socio-legal approach: what is the legal rationale that Nigerian courts have used in cases concerning limitations to freedom of religion or belief? The article will first explore the history of freedom of religion in Nigeria with a focus on factors that influence its application in the country; and second, Nigerian courts' interpretation of the concept with specific reference to the legal rational the courts have used. Third, the article discusses the approach of the courts to the application of the proportionality test to balance the regulatory power of the state and citizens' right to practice their religion. In order to achieve its objectives, this article examines a number of cases decided by Nigerian courts on freedom of religion, mostly from High Courts and Courts of Appeal. The

1 Audrey Peltze, 'A Survey of Constitutional Challenges to Municipal Regulation of Religious Solicitation and a Suggested Legislative Compromise', 11:4 Fordham Urban Law Journal (1982); Kenneth Lasson, 'Incitement in the Mosques: Testing the Limits of Free Speech and Religious Liberty', 27:3 Whittier L. Rev. (2005-2006); Isaac Tarwase Sampson, 'Religious Violence in Nigeria: Causal Diagnosis and Strategic Recommendations to the State and Religious Communities', African Journal on Conflict Resolution (2012); Brian J. Grim and Roger Finke, The Price of Freedom Denied (New York: Cambridge University Press, 2011); Monica Duffy Toft et al., God's Century (London: W.W. Norton \& Company, 2011), A.A. Anwar, Gardawa, Ulama and the State of Northern Nigeria: The Maitatsine phenomenon, 1962-1985 (Ph.D. dissertation, University of Maiduguri, 1997); H. Wakili, The Phenomenon of Revolts and Riots in Kano, 19831995: An Historical Perspective (Ph.D. dissertation, Bayero University Kano, 1997); and Sam Amadi, 'Kaduna Anti-Preaching Law: A Regulatory Misstep', This Day Newspaper, 19 April 2016, pp. 11-19.

2 Sampson, supra note 2, p. 120.

3 Amadi, supra note 2, p. 7.

4 Inibehe Effiong, 'Kaduna Preaching Bill: Resolving the Constitutional Controversy', Punch Nigeria, published in three instalments on 1 April 2016 at p. 20, 4 April 2016 at p. 26, and 5 April 2016 at p. 23. 
article contains contributions from several scholars, religious groups, public officials, and non-governmental organisations obtained through interviews at their various offices.

\subsection{History and Development of Freedom of Religion in Nigeria}

Nigeria became an independent country on 1 October 1960 with its new Independence Constitution that contained provisions on fundamental human rights that remained without amendment since $1960 .{ }^{5}$ The provisions were inserted to address problems associated with ethnic and religious minorities in the country. The idea was to protect minorities across the different parts of the country against possible domination by majority ethnic and religious groups in the country including the alleged forceful imposition of the religion of Islam on minority Christian groups in Northern Nigeria. The provisions originated from the Universal Declaration of Human Rights adopted by member states of the United Nations in 1948. The UN Charter, agreed in 1945, declared that one of the purposes of the United Nations was 'promoting and encouraging respect for human rights and fundamental freedoms for all without distinction as to race, sex, language, or religion' ${ }^{6}$

\subsection{Religious Demography and Diversity}

Nigeria is a religiously diverse country with several challenges related to freedom of religion or belief. Since 2009, tensions caused by Boko Haram and the Islamic Movement of Nigeria (IMN) alone claimed more than 10,000 innocent lives, traumatised millions, caused massive destruction of property, and disharmony among Nigerians. ${ }^{7}$ Nigeria's population was estimated at 190.6 million as at July 2017. ${ }^{8}$ Out of this number, 49.3 per cent are Christians and 48.8 per cent Muslims, and the remaining 2 per cent represents other faiths or no religion at all according to a 2012 survey by the Pew Research

5 Constitution of Nigeria 196o, Chapter 4, Sections 32-45.

6 Charter of the United Nations (1 UNTS XVI), Article $1(3)$.

7 See Paul Lubeck, 'Islamic Protest under Semi-Industrial Capitalism: "Yan Tatsine" Explained,' 55:4 Africa (1985), pp. 369-89; and James Grow et al. (eds.), Militancy and Violence in West Africa: Religion, Politics, and Radicalization (New York: Routledge, 2014).

8 United States Center for International Religious Freedom (USCIRF), Annual Report 2017, www.state.gov/documents/organization/281018.pdf, accessed 23 October 2018. 
Center's Forum on Religion and Public Life..$^{9}$ In reality however, neither the religion of Islam nor Christianity can claim to be bigger than the other in the country. ${ }^{10}$

On religious sects' affiliation, research indicates that in Northern Nigeria, 38 per cent of Muslims are Sunni comprising of 19 per cent Tijaniyya, 9 per cent Qadriyya and the Salafists such as the Izala, (Jama'atu Izalatil Bid'a Wa'ikamatis Sunnah) often also called JiBwis and the Radicals such as the Boko Haram and Ansaru who are hardline terrorist groups. ${ }^{11}$ Among the non-Sunnis are about 12 per cent Shia whose several clashes with authorities caused the death of many innocent people, 3 per cent Ahmadiyya and Maitatsine/Kala Kato, best known for their clashes with the authorities in Kano in 1980s and subsequently in Borno, Kaduna and Adamawa states, also resulting in the death of more than 50oo Nigerians. There are also Christian groups in the country comprised of Evangelicals, Roman Catholics, Anglicans, Pentecostals, Baptists, Methodists, Presbyterians, members of the Latter-day Saints Church (Mormons), and Jehovah's Witnesses. ${ }^{12}$

In fact, Northern Nigeria with the persistent religious troubles it has experienced, has been home to members of different religious beliefs even before the 1950s. The religious affiliation census of $195^{2}$ indicates that population of Muslims in the states of North Nigeria was 73 per cent, Christians 2.7 per cent, and Animist and others 24.3 per cent. In 1963, the Muslim population decreased to 71.7 per cent, the Christian population increased to 9.7 per cent, and the Animist and "others" population decreased to 18.6 per cent. However, the change in several states, such as Kaduna and Benue, were much more striking, as demonstrated in the table below:

See The Future of World's Religions: Population Growth Projections (2010-2050), available at www.pewresearch.org, accessed on 14/o9/2019.

10 Is-haq O. Oloyede et al., "The Operational Complexities of the "Free Exercise" and "Adoption of Religion" Clause in the Nigerian Constitution', in Pieter Coertzen et al., Religious Freedom and Religious Pluralism in Africa: Prospects and Limitations (Stellenbosch: Sun Media, 2016), p. 86; M. Tabiu, Sharia Federalism and Nigerian Constitution, paper presented at the International Conference on Sharia in London, 2004 (cited in J. Tyus), Going Too Far: Extending Shari's Law in Nigeria from Personal to Public, 3 Washington University Global Studies Law Review (2004), p. 199. See also A.H. Yadudu, 'The Separation of Church and State: Nigeria's Constitution Contrivance', 1:2 Lawyers Bi-Annual Journal of Nigerian and Comparative Law (1994), pp. 14-37.

11 Ibid.

12 USCIRF, supra note 9. 


\begin{tabular}{|c|c|c|c|c|c|c|}
\hline \multirow{2}{*}{$\begin{array}{l}\text { Present State } \\
\text { (ex-North) }\end{array}$} & \multicolumn{3}{|l|}{$195^{2}$} & \multicolumn{3}{|l|}{1963} \\
\hline & $\%$ Muslim & \% Christian & $\begin{array}{l}\% \text { Animist } \\
\text { and other }\end{array}$ & $\%$ Muslim & \% Christian & $\begin{array}{l}\% \text { Animist } \\
\text { and other }\end{array}$ \\
\hline \multicolumn{7}{|c|}{ North-West Geo-political Zone } \\
\hline Sokoto & 96.3 & 0.5 & 3.2 & 98.9 & 0.4 & 0.7 \\
\hline Zamfara & 96.3 & 0.5 & 3.2 & 98.9 & 0.4 & 0.7 \\
\hline Jigawa & 98.4 & 0.4 & 1.3 & 98.0 & 0.8 & 1.2 \\
\hline Kano & 97.8 & 0.5 & 1.7 & $97 \cdot 0$ & 1.1 & 1.8 \\
\hline Katsina & 95.2 & 0.3 & 4.5 & 94.6 & 0.4 & 5.1 \\
\hline Kebbi & 79.0 & 0.3 & 20.7 & $85 \cdot 5$ & 0.5 & 14.0 \\
\hline Kaduna & $57 \cdot 3$ & 10.2 & 32.5 & $55 \cdot 7$ & 25.1 & 19.2 \\
\hline \multicolumn{7}{|c|}{ North-East Geo-political Zone } \\
\hline Yobe & $87 \cdot 3$ & 0.5 & 12.2 & 94.8 & 1.0 & 4.2 \\
\hline Borno & 80.9 & o.6 & 18.5 & 88.3 & 2.7 & 8.9 \\
\hline Bauchi & 76.3 & 1.1 & 22.6 & 83.4 & 1.6 & 14.9 \\
\hline Gombe & 70.1 & 2.5 & $27 \cdot 4$ & $75 \cdot 0$ & 6.2 & 18.8 \\
\hline Adamawa & 32.9 & 3.8 & $63 \cdot 3$ & 34.6 & 16.0 & $49 \cdot 4$ \\
\hline Taraba & 19.0 & 2.0 & 78.0 & 26.2 & $13 \cdot 7$ & 60.0 \\
\hline \multicolumn{7}{|c|}{ North-Central Geo-political Zone } \\
\hline Kwara & $63 \cdot 4$ & 6.5 & 30.1 & $75 \cdot 6$ & 13.6 & 10.8 \\
\hline Niger & 46.8 & $3 \cdot 5$ & $49 \cdot 7$ & 62.4 & 4.0 & 33.6 \\
\hline Kogi & 22.5 & 18.5 & $59 \cdot 1$ & $37 \cdot 5$ & 28.2 & 34.2 \\
\hline Nasarawa & 23.4 & 7.8 & 68.8 & 30.2 & 13.8 & 56.0 \\
\hline Plateau & $25 \cdot 5$ & 11.4 & 63.1 & 26.1 & 23.2 & 50.7 \\
\hline Benue & 2.8 & $7 \cdot 1$ & 90.1 & 2.8 & $53 \cdot 4$ & 43.8 \\
\hline \multicolumn{7}{|l|}{ Total North } \\
\hline Total North & 73.0 & 2.7 & $24 \cdot 3$ & 71.7 & $9 \cdot 7$ & 18.6 \\
\hline
\end{tabular}

This information demonstrates the nature of religious diversity in Northern Nigeria from 1952 to 1963 as between Muslims, Christians, and Others (principally "animists" or "pagans", that is followers of African Traditional Religions), in different parts of the north. Ultimately, it showed Muslims as the majority in terms of religious affiliation. The increase and decrease in population of Muslims, Christians and the animists in some instances are indicative of the operation of religious propagation by both Muslims and Christians. 
Nevertheless, no subsequent census or systematic survey has collected similar data about Nigeria since then.

\section{$3 \quad$ Managing Religious Diversity}

3.1 Legal Framework for the Protection of Freedom of Religion or Belief

As a democratic country, Nigeria's Constitution provides, firstly, that no one has the right to demand the adoption of one's religion as the official religion of 'the government of the Federation or of a State. ${ }^{\prime 3}$ Second, the citizens of Nigeria must exercise the right in a manner that is consistent with the supremacy of the Constitution. ${ }^{14}$ This is a guiding principle that considers the indivisibility and indissolubility of the country as inviolable. ${ }^{15}$ Thus, it would be an unlawful exercise of religious rights to assert them as a justification by 'any person or group of persons to take control of the government of Nigeria or any part thereof.'16 Most relevantly, the exercise of the right to religious freedom, individually or communally, is subject to the exigency of public order and public safety which, when threatened, obligates the government to provide, maintain and secure 'such supplies and services as may be designated by the National Assembly as essential' for their restoration. ${ }^{17}$

Section 38(1) of the Constitution makes provision for the citizen's 'freedom of thought, conscience and religion, including freedom to change his religion or belief, and freedom (either alone or in community with others, and in public or private) to manifest and propagate his religion or belief in worship, teaching, practice and observance.' Section 39(1), subsequently, provides that 'every person shall be entitled to freedom of expression, including freedom to hold opinions and to receive and impart ideas and information without interference', while Section 40 guarantees that 'every person shall be entitled to assemble freely and associate with other persons.' These are the granting clauses that give the citizens of Nigeria the constitutional right to engage in religious propagation within the shores of Nigeria among other rights; to associate and to hold opinions or to impart ideas without any hindrance.

13 See Constitution of Nigeria, Sec. 10. For a discussion of this provision, see Simeon O. Ilesanmi, 'Disestablishment Without Impartiality: A Case-Study Examination of the Religious Clauses in the Nigerian Constitution', 85:2 St. John's Law Review (2011), pp. $568-569$.

14 See Sec. 1(1) and (3).

15 See Sec. 2(1).

16 See Sec. $2(1)$.

17 See Sec. 11(1). 
However, these rights are not absolute. The Constitution gives the state power to derogate from them through laws that 'are reasonably justifiable in a democratic society.' Specifically, Section 45(1) provides that 'nothing shall invalidate any law that is reasonably justifiable in a democratic society in the interest of defence, public safety, public order, public morality or public health; or for the purpose of protecting the rights and freedoms of other persons.'

The decisive terms in the provision are as follows. First, a law that is "reasonably justifiable". Second, the requirement of "democratic society". Third, the grounds must be any of the following or a combination thereof: "defence", "public safety", "public order", "public morality", "public health", and to "protect the rights of others". The meaning of this provision is that governments do not have the right to limit the enjoyment of the right as they deem fit - unless and until the conditions mentioned in the provision are satisfied. This means that limitations may be applied exclusively for those purposes for which they were prescribed and must be directly related and proportionate to the specific need on which they are predicated.

The questions that come to mind however are, i.a.: what is the meaning of the phrase "reasonably justifiable law"? What are the criteria for its determination? What is the meaning of "democratic society"? In addition, the third requirement as shown above is that the law must pursue a legitimate aim - the protection of 'public safety, order, health, or morals or the fundamental rights and freedoms of others.' But what comes within the purview of these legitimate aims? The Constitution is silent on the meaning of these phrases.

\subsection{Religion-State Relation in Nigeria}

In order to understand the result of the operation of the legal framework for the management of Nigeria's religious diversity, there is a need to understand the country's religion-state pattern first and its implication for freedom of religion. Even though scholars are still debating the meaning of Nigeria's religion-state pattern under Section 10 of its Constitution, research demonstrates that there is a difference between theory and practice in Nigeria's religion-state relation. It suffices to say that there is a hybrid system in Nigeria. At the vertical level, the model is one of religious preference for Islam and Christianity. At the horizontal level, there are various religious favouritism regimes, with some exhibiting establishment or endorsement models or both. Some exhibit a religious preference model, but others, such as Lagos State, exhibit a regime of benevolent neutrality. In summary, the trend in Nigeria is that, in contrasts to what other scholars have said about Nigeria's religionstate pattern, states in Nigeria show favouritism to the dominant religions of Islam and Christianity in such a way that, where the state is a predominantly 
Muslim state, it favours Islam; and where it is predominantly Christian, it favours Christianity. ${ }^{18}$

This pattern has legal implications for freedom of religion and belief for Muslims and Christians in the country. On the Muslim side, the impact is negative to their freedom of religion, especially for new Muslim groups in the region. This is evidenced in the area of regulation of Islamic religious preaching, in particular, beginning in the 1960 os in some states in the region as discussed in detail in the next section. ${ }^{19}$ In summary, the experience in Nigeria from 1970 to 1980 os indicates the negative impact of Nigeria's religion-state pattern on Muslims minority religious groups.

\subsection{Regulation of Religious Preaching}

Regulation of preaching in Northern Nigeria may have started with the attempt by the king of Gobir, Bawa Jan Gwarzo, in the late eighteenth century to control the Islamic religious preaching of Usman dan Fodio before the launching of the latter's jihad. ${ }^{20}$ Second was the attempt to regulate Islamic preaching during the colonial administration in 1926 as a result of incessant disagreements between the dominant Islamic religious groups in the northern region. This effort continued up to 196o when Nigeria became independent and gained a new constitution. ${ }^{21}$ This Constitution provided for the first time full liberal rights, including the freedoms of religion, expression and association. ${ }^{22} \mathrm{~A}$ third attempt to control religious preaching, however, occurred soon afterwards, and it was designed to control minority religious groups called Gardawa, perceived as dissidents in the region by authorities in favour of the dominant Sufi religious groups.

Major sources of conflict between some Gardawa and people in the early 196os among other things were their denunciation of Tasawwuf and the Sufi brotherhoods as well as their opposition to the use of Hadith and other related

18 Ahmed S. Garba, 'Nigeria's State-Religion Relation and its Legal Implications to Freedom of Religion', Pieter Coertzen et al. (eds) Religious Freedom and Religious Pluralism in Africa: Prospects and Limitations (Stellenbosch: Sun Media, 2016), pp. 157-175.

19 Ibid.

20 Gwandu, Abubakar, 'Aspects of the Administration of Justice in the Sokoto Caliphate and Shaykh Abdullahi ibn Fodio's Contribution to it', in K.S. Rashid (ed.), Islamic Law in Nigeria, (Kaduna: Islamic Publications Bureau, 1986), pp. 10-27. See also Ricardo Rene Laremont, Islamic Law and Politics in Northern Nigeria (New Jersey: Africa World Press, 2011), pp. 64-65.

21 Haruna Wakili, The Phenomenon of Revolts and Riots in Kano, 1893-1995 (Ph.D. dissertation, Bayero University Kano, 1997), pp. 38-45.

22 See Constitution of Nigeria, Chapter IV. 
books of the Shariah besides the Qur'an. ${ }^{23}$ Their various open-air preaching practices popularly called Wa'azin Turmi (preaching while seated on a bench-like stool made from trees) which is specifically associated with the Muhammadu Marwa Gardawa group, Wa'azin Fitilar Ruwa (preaching with the aid of a lantern), Wa'azin Kasuwa (preaching at the market place), Wa'azin Kan Hanya (preaching by the roadside) became popular in Kano. ${ }^{24}$

Leaders of the Sufi brotherhoods in Kano capitalized on these trends in Gardawa as basis for their collaboration with the government of the various states in Northern region to persecute and remove the religious activities of Gardawa from the religious marketplace. Their collaboration yielded positive result for them between 1962 and 1975. For example, the Fityanul Islam Organisation, the political wing of the Tijjaniyya Sufi order in Nigeria protested against the preaching of Gardawa on 7 January 1964 in a petition they wrote to the premier of Northern Region, Sir Ahmadu Sardauna of Sokoto, ${ }^{25}$ who remained liberal and ecumenical in matters of religion until he was killed in the military coup of $1966 .{ }^{26}$

In the Kano State in particular, to address the problem, the Emir of Kano designed some rules called the Kano Local Government Area Quranic Interpretation and Admonishing Rules which became public on 4 September 1967. ${ }^{27}$ But possibly because of the civil war that broke out in 1967, nothing happened because Gardawa had vanished from the scene. They re-emerged towards the end of the war in 1969 and continued preaching without a license in Kano. In reaction the Sufi brotherhoods' ulama in Kano persuaded the Emir of Kano to discuss with the Governor of Kano State, Alhaji Audu Bako on the need to design social control measures against Gardawa religious preachers to avoid a possible breakdown of law and order in the state. The Governor later authorised the Emir to establish a Committee of ten Islamic scholars to screen Islamic religious preachers in the state and certify them as fit and proper before they were allowed to engage in public religious preaching or Quranic translation.

In compliance, the Emir formed a committee comprised of leading scholars from the dominant Sufi orders in the state. This committee included Sheikh Nasiru Kabara (d. 1996), Sheikh Tijani Usman (d. 1970), Shehu Maihula (d. 1988)

23 Gardawa Anwar Auwal, Ulama and the State in Northern Nigeria: The Maitatsine Phenomenon, 1962-1985 (Ph.D dissertation, University of Maiduguri, 1997), p. 102.

24 Ibid., p. 103.

25 Ibid., p. 103.

26 Mathew Hassan Kuka, Religion, Power and Politics in Northern Nigeria (Ibadan: Spectrum Books Limited, 2011), pp. ix-xiii.

27 Anwar Auwal, supra note 24, p. 107. 
and Sheikh Sani Kafanga (d. 1989). The composition of the committee made it clear that the Emir was influenced by members of the dominant Sufi brotherhoods in forming the committee. This effort paved the way for the enactment of the 1970 Kano Preaching Board Law on the basis of which Gardawa were denied license to preach in Kano. ${ }^{28}$

Then Izala, a Wahhabi-oriented Islamic religious group close to Gumi and strongly opposed to Sufi doctrines and practices, emerged on the scene in $1978 .^{29}$ The emergence of Izala changed the equation of the Muslim intrareligious conflict in Northern Nigeria from Qadiriyya vs. Tijaniyya to Tariqa (i.e. Qadiriyya and Tijaniyya collectively) vs. Izala. It immediately began a campaign of offensive preaching directed against Sufi doctrines, which it labelled as bid'a (heretical innovation) and shirk (polytheism). In their preaching, Izala preachers used to mention openly the personal names of the founders of Sufi orders. They engaged in Takfir and even split their mosques from those of the Sufi orders, as they did not allow their members to follow an imam affiliated to a Sufi order. This led to a series of skirmishes between the two groups. ${ }^{30}$

While the imbroglio between Izala and Tariqa groups continued, some of the disgruntled Gardawa re-emerged on the scene in the form of the Yan Tatsine. They were the followers of Muhammadu Marwa Maitatsine, a peripatetic preacher from northern Cameroon who had settled in Kano where he had engaged in belligerent public preaching against all the existing Islamic groups in the region. ${ }^{31}$ Maitatsine's doctrines were different from those of both Izala and Tariqa. For example, while both Izala and Tariqa accepted the Qur'an and the Hadith as dependable sources of divine revelation, and the Sunni jurisprudential tradition (Figh) as a valid body of interpretation, Maitatsine discarded all except the Qur'an. In 1980, the Maitatsine movement engaged in a militant uprising in Kano State. The ensuing military operation left thousands dead, and public opinion in the country became increasingly supportive of the need to regulate religious preaching. ${ }^{32}$

The next major skirmish that happened in Nigeria was the Boko Haram terrorist attacks which are continuing although the government has reduced its effect significantly. It also started because of government regulation of religious preaching in Borno State, which led to a major face-off between members of

\footnotetext{
28 Ibid., p. 264.

29 Ibid.

$30 \quad$ Ibid.

$31 \quad$ Ibid.

32 M.U. Sani, 'Changing Islamic Identity in Nigeria from the 196os to the 1980s: From Sufism to anti Sufism' in L. Brenner (ed.) Muslim Identity and Social Change in Sub-Saharan Africa (Bloomington and Indianapolis: Indiana University Press, 1993), pp. 154-178.
} 
the Boko Haram and the government of Nigeria leading to the extra-judicial killing of the group's leader, Mohammad Yusuf, and many of his members and other citizens of Nigeria. It is, however, pertinent to mention that Borno State enacted the Islamic Religious Preaching Board Law in Northern Nigeria in 1977. This law was enacted because of the activities of the religious activities of Gardawa religious group in Maiduguri which started manifesting itself in their religious preaching sessions at Kukar 'Yan Bori in Gwange ward in early 1970. ${ }^{33}$

It was this experience in Borno and the experience in Kano that gave rise to the enactment of the religious preaching law in Borno State in 1977, making the state to become the second state to enact such a law in Northern Nigeria. ${ }^{34}$ A possible explanation for this is a lot of Gardawa that suffered suppression in Kano between 1973 and 1975 relocated to Maiduguri and reside in Gwange ward. ${ }^{35}$ This includes those of them that were released from detention in 1975 as mentioned elsewhere in this work. They later relocated to Bullum Kuttu because their bad relationship with people in Gwange ward. ${ }^{36}$ The situation became tense in 1981 especially with the return of more Gardawa to this area after the downfall of Maitatsine in 1980. The state responded by amending and replacing the Religious Preaching Board Law of 1977 with the Islamic Preaching Board law of 1981.

The situation remained calm up to sometime in July 1982 when the Borno State Intelligence Committee reported to the Commissioner of Police of the state on the group's new strategy which saw them reorganising their followers in large numbers in Bullum Kuttu and in other towns such as Biu, Gujba and Gashua in the state. ${ }^{37}$ The Commissioner of Police of Borno State in the person of Tahir Jidda again received another security report on 19 October 1982 on the activities of followers of Maitatsine in the same Bullum Kuttu who had allegedly planned to eliminate some people in the state. Based on these security reports, the security arrested sixteen of them at their preaching session near the Shehu of Borno's palace on 25 October 1982. The next day, the police convened a meeting with members of the Islamic Religious Preaching Board in the state at the end of which the police advised Preaching Board under the leadership of Sheikh Sherif Ibrahim Saleh to design control measures to stop unorthodox Islamic religious preaching in the state..$^{38} \mathrm{~A}$ question to ask here is

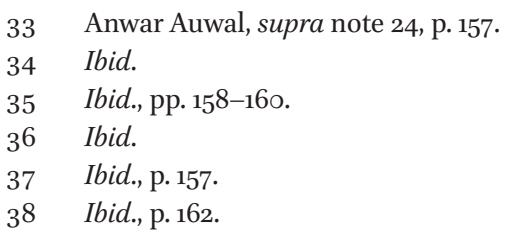


what constitutes "unorthodox religious preaching"? How is it determined and who is competent to determine it?

The attempt to control Gardawa ended in a collision between them and the Police, which later became known as the Bullum Kuttu crisis in Borno State. Police succeeded in overpowering the group and in the process killed the leader of the group in the person of Muhammadu Rufa'i (alias Gajere). ${ }^{39}$ In addition, a total of one hundred and eighteen people, including sixteen police officers lost their lives in the encounter. This was the situation up to 2009 when the Boko Haram situation broke out in Borno State as result of which the 1981 religious preaching law was amended and replaced with the Borno State Islamic Preaching Board Law 2010 (as amended).

Another good example is the Kaduna State. The Kaduna State, like Kano and Borno, experienced its own version of mutiny associated with Islamic religious groups; Maitatsine and the Shiite are examples. And it was as a result of these two experiences that the state enacted its first religious preaching law called the Kaduna State Religious Preaching Edict No. 7 of 1984. This law remained in operation up to 1987 when it was amended by the regulation of religious preaching amendment edicts No. 1 of 1987 and later by preaching law No. 6 of 1996, respectively. The 1996 law continued to be in operation until December 2015 when the state experienced the Shiite clash with the Nigerian Army and as a result the state proposed to replace the 1996 preaching law in the state with the Kaduna State Religious Preaching Bill of 2016.

\subsection{Reasons for the Regulation of Religion and Preaching}

In northern Nigeria, from the history explored, the reasons for this type of regulation may be security and the protection of the rights of other citizens. This is because the manner of religious preaching has become problematic in Northern Nigeria in particular and it has given rise to intra-Muslim conflicts in the region with devastating consequences on the polity. In this region, sometimes some Islamic religious preachers use belittling remarks in their preaching sessions against adherents of other religious groups or become intolerant of others. They may also engage in harsh religious propagation or preach hatred to their own congregation. ${ }^{40}$ In other instances, they legitimise or incite the commission of crimes against others, excommunicate their co-religionists of other sects, or call them to repent from their sinning or "unbelief". In addition, when preaching to some uneducated and credulous followers, they misguide them into religious beliefs and practices that are "clearly in error"; such as it is

39 Ibid., p. 164.

40 Information on this assertion is contained in the interviews conducted for this project. 
Haram to attend any "western-style" school in Nigeria or study any "Western" subject. Even though the potential danger in these remarks is obvious considering that Northern Nigeria is a home to different religions and ideologies, and a place where much intra-Muslim conflict has happened. Nevertheless, these and other reasons may qualify in the eyes of the state as legitimate grounds for restricting citizens' right to freedom of religion including the right to engage in religious preaching in the interest of public safety.

A key person in Borno state provided general information in an interview on why, for example, the Borno state Islamic Religious Preaching Board Law was enacted and how it operates. According to Sheikh Goni Mohammed Saad Ngamdu the enactment of the Islamic Preaching Board law in 1981 was aimed at controlling Islamic religious preachers who engage in Islamic religious preaching without 'proper knowledge, preaching just anyhow; especially Izala coming to criticize and make trouble in the state. ${ }^{31}$ According to him, the Preaching Board comprises of a chairman, one representative from each Emirate Council, to be so appointed by the Council, three representatives from groups of Islamic religious preachers in the state and the Governor nominated Sheikh Goni Mohammed Saad Ngamdu of the Jama'atul Nasril Islam who is a known member of the Tijjaniyya group, Sheikh Muhammad Abba Aji a known Wahabi/Izala member and Goni Sanda a neutral party. The Governor also nominated three other persons; Sheikh Ibrahim Salih, Sheikh Abubakar el-Miskin a popular Tijanija adherent and Goni Kaltumi, a popular adherent of Tijjaniyya Sufi group. ${ }^{42}$ These religious leaders have continued on the Board up until 2010 but before the amendment of the law. ${ }^{43}$

In terms of functions, the Board was to determine and regulate the qualification required of any person to become an Islamic religious preacher or a Qur'anic interpreter and make recommendations to the appropriate Emirate Council, to conduct examinations and set standards for any person desirous of becoming an Islamic religious preacher or a Qur'anic interpreter, to compile and approve sets of Islamic religious poetry or songs that may be permitted

41 Sheikh Ngamdu is the North East Zonal Coordinator Jama'atu Nasril Islam and Borno State Secretary General of the same organization. He gave this information in 12 May 2012, in an interview granted to Dr. Philip Ostien; formerly of the Faculty of Law of the University of Jos in Nigeria, a copy of which is with the author. In addition, he belonged to the Tijjaniya majority religious group predominant in Borno State.

42 Their affiliation to the Tijaniya Sufi order is well known in Nigeria.

43 Referring to when the interview was granted. It should also be noted that he confirmed that some them are deceased now. He mentioned the name of Shaikh El-Miskin, Shaikh Muhammad Abba Aji, and others, as examples of people who had died. The Preaching Board still reflects the dominant religious group composition today. 
in mosques or in the public places and to regulate and determine the type of Islamic religious poetry or songs to be approved for public consumption and dissemination in public preaching or places of worship.

According to the interviewee, the committee had issued preaching licenses to intending Islamic religious preachers on specific subjects in the state. They did not discriminate against the sect in their operations. They only tried to be sure that a preacher knew whatever subject it was that he wants to preach. Nevertheless, sometimes there were complaints: people who were disqualified or unqualified and not given licenses would say that they had been discriminated against because of their beliefs. There are instances where the Board even withdrew licenses (or certificates) from preachers. For example, at some point the Board withdrew the preaching license of Sheikh Muhammad Abba Aji because he was causing "confusion," calling other Muslims unbelievers. Another example was one Usman Bida; he was asked to give his opinion on the relation between Muslims and non-Muslims. He said: 'War!' His license was suspended for two years. But the Islamic Preaching Board Law still exists in Borno state and they have so far issued about 500 licenses from 1981 to 2010 before the amendment of the law. ${ }^{44}$

The whole argument relies on the "perceived inflammatory nature, incitement and incivility" of religion to justify the need for its control because according to the state, it is a threat to public order. This argument is counterintuitive because the government may use it to justify scapegoating religious minorities in favour of religious majorities. Karren Armstrong is a relevant author here with her famous work entitled Fields of Blood: Religion and the History of Violence. ${ }^{45}$ In this book, the author debunks the claim that religion has been the cause of all major wars in history arguing that other factors have caused such violence without any contribution from religion. Another problem is the argument relies on speculative consequentialism to support restriction of religious preaching and religion at large in the society. This is because it has not taken actual occurrences of events into account before arriving at the conclusion. It is therefore impossible to identify all the possible consequences of the so-called or perceived danger of religion in the circumstance let alone knowing whether it is harmful or beneficial. Another problem here may be making the state the sole guardian of its conscience. This is because the emphasis is on duty alone without providing any explanation on the determination of what comes within the purview of inflammatory nature; no information about any

$44 \quad$ As of 2012.

45 Karen Armstrong, Fields of Blood: Religion and the History of Violence (London: The Bodley head, 2014). 
criteria for its determination. The absence of any valid explanation gives room for abuse. Therefore, the main problem has always been the extent to which the state can restrict the citizens' rights without violating the law.

\section{4}

\section{Legal Rationale}

\subsection{Interpretation of Freedom of Religion Cases}

There are two situations to consider in discussing this topic. First, where a court is faced with an enactment that seeks to limit the enjoyment of freedom of religion and second, where the court is to interpret the provision directly. ${ }^{46}$ A particular legal order may provide for a stronger or a weaker judicial review. ${ }^{47}$ But an important issue of judicial review is the method of interpretation employed by courts in construing constitutional provisions. ${ }^{48}$ In some legal systems, the Parliament or the legislature is more powerful than the courts such that any decision that did not go down well with them can be overturned. ${ }^{49}$ This has an implication on the role of the courts in filling normative gaps in the Constitution.

In Nigeria, the trend is that the courts will generally invalidate an enactment where it goes contrary to the procedure laid down in the Constitution as in A.G. Bendel State v. A.G. Federation and Ors; ${ }^{50}$ or where the legislature is found to have exceeded its powers in the making of a law as in Lakanmi v. A.G.(West)and Ors; ${ }^{51}$ or where an act of legislation contravenes the provisions of the Fundamental Human Rights section as in Shugaba Darman v. Minister of Internal Affairs and Ors; $; 2$ or where the exercise of powers of one organ usurps the constitutional powers of the other organ or otherwise goes contrary to the provisions of the Constitution as in A.G. (Ogun) State v. A.G. Federation and $\mathrm{Ors} ;{ }^{53}$ and finally where any legislation ousts the jurisdiction of the courts as in Ademolekun v. University of Ibadan. ${ }^{54}$ These are general cases on fundamental

46 In the first scenario, there are two models of judicial review in the world today; the "American model" and "the Continental European model". See Albert H.Y. Chen and Miguel Poiares Maduro, 'The Judiciary and Constitutional Review', in Mark Tushnet et al. (eds) Routledge Handbook of Constitutional Law (New York: Routledge, 2013), pp. 97-107.

47 Ibid., pp. 97-105.

48 Ibid.

49 Ibid., pp. 104-105.

$5^{\circ} \quad$ (1982) 3 N.C.L.R. $35^{8}$.

$51 \quad$ (1971) U.I.L.R. 201.

$52 \quad(1982) 2$ N.C.L.R. 459.

53 (1982) 3 N.C.L.R. 166.

54 (1968) N.M.L.R. 253. 
human rights based on specific provisions. The problem under investigation in this work is that the Constitution has not defined the extent of derogation from the right to free exercise of freedom of religion. Nigerian courts are yet to get the opportunity to make any pronouncement on Preaching Board Laws generally.

On the second scenario however, there are relevant cases to show the departure of the Nigerian courts from the American-style jurisprudence adopted in the case of Medical and Dental Practitioners' Disciplinary Tribunal v. Okonkwo. ${ }^{55}$ First, is the case of The Provost, Kwara State College of Education, Ilorin \& ORS v. Basirat Saliu \& ORS. ${ }^{56}$ In this case, the Court of Appeal held that a lower court's denial of the use of Niqab/Hijab by a female Muslim student of the College under the pretext of protection of public safety, public order and protection of the rights of others violates the free exercise of religion clause in Section 38 of the Nigerian Constitution. ${ }^{57}$ The court further held that any such restriction or derogation must be within the confines of the conditions stipulated under Section 45 of the Constitution. 58

Although the court did not specifically interpret the meaning of "reasonably justifiable law in a democratic society", or what constitutes defence and public order for the purpose of derogation from the right, it did adopt the deferential approach, which focuses on the self-understanding of the adherent as the baseline for defining what is and what is not religion. In this approach the requirements are the sincerity of the believer and the fact that he did not make his claim for religiosity on a fraudulent basis or for some strategic reasons that are not religious. No wonder the court quoted Section 38 of the Constitution of Nigeria 1999 (as amended) and the Qur'an extensively to support the argument of the respondents. It held that:

One may say, without fear of contradiction that the respondents have a constitutional right to use [the] veil in school or elsewhere save under the exceptions mentioned in the Quran. In chapter 24 verses 30 to 31 the Glorious Qur'an, Allah (swT) has said:

Enjoin believing men to turn their eyes away from temptation and to restrain their $\mathrm{ca}[\mathrm{r}]$ nal desires. This will make their purer. Allah has knowledge of their actions. Enjoin believing women ... to cover their adornment to draw their veils over their bosoms and not to reveal their

(2001) 7 N.W.L.R. (PT.711) 206, paras. 244-245.

56 (2016) 4 S.Q.L.R. (Part III), July-September, pp. 509-55०.

57 Ibid., pp. 533-534, paras. A-C.

58 Ibid. 
finery except to their husbands, fathers, husband's fathers, sons, step sons, brothers, brother's/sister's son, women servants and slave girls; male attendants lacking in natural vigour, and children who have no carnal knowledge of women. ${ }^{59}$

The Court of Appeal maintained this approach in a subsequent case on the right to use the veil in schools in Nigeria. In the case of Asiyat Abdulkareem \& ORS v. Lagos State Government \& ORS ${ }^{60}$ the High Court of Lagos held that the wearing of hijab by female Muslim students in a secular school infringes on the right of non-Muslim students who will feel inferior to the hijab-wearing students. The Court of Appeal reversed this decision in favour of the hijab applying the same reasoning as the previous case. In reversing the judgement of the High Court of Lagos State, the Court of Appeal held in construing the provision of Section 38 of the Constitution that:

Against the provision of section 38 (supra), it is taken that each individual has the basic right to believe what he chooses to worship, whom he pleases and how he pleases, always provided that he does not impermissibly interfere with the right of others. Globally, there are those who believe in nothing; those who believe but doubt, those who worship the JudeoChristian God in innumerabl[e] different ways, Muslims, who worship the Islamic way in sects and versions but mainly anchored on Qur'an and Sunnah of the Prophet Muhammad saw, those who worship themselves; those who worship animals such as cows or monkeys etc., and those who worship several deities, just to mention a few of the remarkable variety of expressions of beliefs and faiths that obtain. More specifically in Nigeria the dominant religious beliefs are Islam and Christianity. Other forms of religious beliefs such as worship of Traditional Tribal or Family gods, River deities, Gods of Iron, Thunder or such other things. All these forms of worship enjoy minority status. Some weekdays or months of lunar or Gregorian calendars are sacred. ${ }^{61}$

First, an interesting point to note in this pronouncement is the acknowledgement by the court of the existence of majority and minority religious groups in Nigeria. Second, the definition is an all-inclusive decision in that all types of religious beliefs are accommodated. It objected to the definition of religion based

\footnotetext{
$59 \quad$ Ibid.

6 (2016) 4 S.Q.L.R. (Part III), July-September, pp. 419-508.

61 Ibid., pp. 467-477, paras. A-C.
} 
on a formal way of worship and reliance on a holy book because of its religious diversity. ${ }^{62}$ In this case, the court affirmed that the Nigerian Constitution guarantees the right to freedom of thought, conscience and religion. In the opinion of the court, by virtue of the provision of Section 38 of the Constitution, a person is free in private or public to manifest and propagate and practice his religion. The limits of this freedom as in all cases are when they impinge upon the rights of others or where they put the welfare of the society or public health in jeopardy. ${ }^{63}$

Likewise, in other cases in Nigeria where the Supreme Court gives protection to freedom of religion, it reaffirms that Sections 37 and 38 of the Constitution allow a patient, even to the point of death, to refuse a particular medical treatment on religious ground. Other cases in this category are Nkpa v. Nkume, ${ }^{64}$ Agbai v. Okagbue, ${ }^{65}$ and Ajao v. Ashiru. ${ }^{66}$

\subsection{Balancing Mechanism}

It was stated above that the Nigerian Constitution is silent about the meaning of expressions such as "reasonably justifiable law" and "democratic society". In addition, the meaning of the phrase "the protection of public safety, order, health, or morals or the fundamental rights and freedoms of others" is unclear. Moreover, scholars have expressed different views on whether words like worship, teaching, practice and observance in the provision indicate traditional ways of manifestation of religion or belief. In addition, whether they can apply to a wider range of beliefs or not. There is also the word manifestation. The question is whether it should be interpreted in a wide way like religion or it should be given a restrictive meaning? Must an action express a religious belief or not before it qualifies as such? What kind of link must there be present between action and a belief before such manifestation become legitimate? Nigerian courts are still silent on the meaning of these phrases.

This article analysed the following question: what is the legal rationale that Nigerian courts have used in cases concerning limitations to freedom of

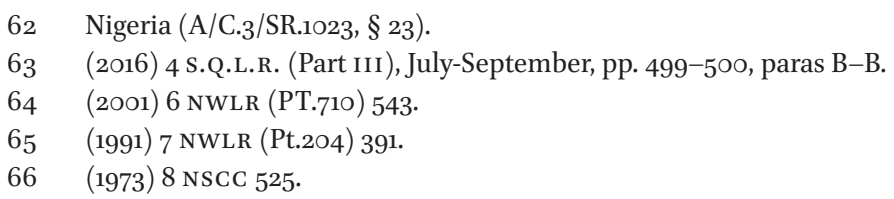


religion or belief? At the end of this analysis, the article established that first, the Constitution of Nigeria did not define influential terms in the provision such as the phrase "reasonably justifiable", "democratic society" and the criteria for determining such a law. The Constitution did not also define what comes within the purview of phrases such as defence, public health, public morality etc or even the right of others that it seeks to protect. The lack of definitions allows the government to determine the meaning of those terms in derogating from the rights. In addition, the meanings of words like manifestation, worship, teaching, practice and observance in the provision are not provided for. Nobody knows whether they can apply to a wider range of beliefs or not. Second, the religion-state pattern of the country indicates in contrast to what many believe, that there is a difference between theory and practice in the pattern. The country identifies positively with religion in its affairs. In addition, the religion-state relationship of Nigeria influences or affects the application of the limitations depending of the area. This means that where Islam is predominant, it is favoured against Christianity and vice versa. This may be a possible explanation why regulation of preaching affects freedom of religion of the citizens especially and that the government mostly capitalizes on the issue of security and the need to protect the right of others.

First, there should be definitions of all-important phrases used in the language of freedom of religion provision so that the state is not allowed to determine the meaning of such terms and phrases alone and the way they want it. As a democratic state, the government must always show reasons as to why certain limitations are really needed and appropriate otherwise there would be abuse. Courts not just in Nigeria, including the European Court of Human Rights (as other contributions in this special issue establish), have not always been straightforward in demanding precise and diligent handling of limitation clauses. Even though there is evidence of breaches of security in Nigeria by religious groups such as the Boko Haram, threads to public health, morality and violation of the right of other Nigerians, the government must still be required to satisfy the conditions in the provision before derogating from the rights. The Governments should not be allowed to invoke an alleged necessity of limiting freedom of religion in the interest of some "higher goods", which they define as they wish. This article hence proposes that governments must always be required to justify their action for the purpose of "balancing" rights. The need for the state to be forced to justify its action manifests itself in the wording of Section 45 of the Constitution as quoted above in which the phrase "reasonably justifiable in a democratic society" functions as a reminder that any proposed limitation should be considered illegitimate unless and until it meets all the criteria laid down for justifying a limitation. Section 45 does not 
grant Government general permission to "balance" rights to freedom, on the one hand, and limitations, on the other, in ways that suit their political purposes. Such restrictions must not be allowed on grounds not specified under the provisions. In addition, restrictions may not be imposed for discriminatory goals or applied in a discriminatory fashion.

Second, states should re-examine their Preaching Laws with a view to checkmating likelihood of arbitrariness and religious gerrymandering. This is to ensure their neutrality. This can be achieved through enlightenment campaigns to educate people on the meaning and values of freedom of religion and belief. In this regard, judges should also be trained through workshops to understand how these legitimate limitations should be interpreted and how courts elsewhere have interpreted them. Nevertheless, for a smooth operation of freedom of religion and belief in Muslim majority societies, the concept should be repackaged and presented through the framework of Islam and presented as tool for negotiation, rather than norms that are universal and higher than Sharia norms in such societies. 